\title{
WRITERS IN CONVERSATION
}

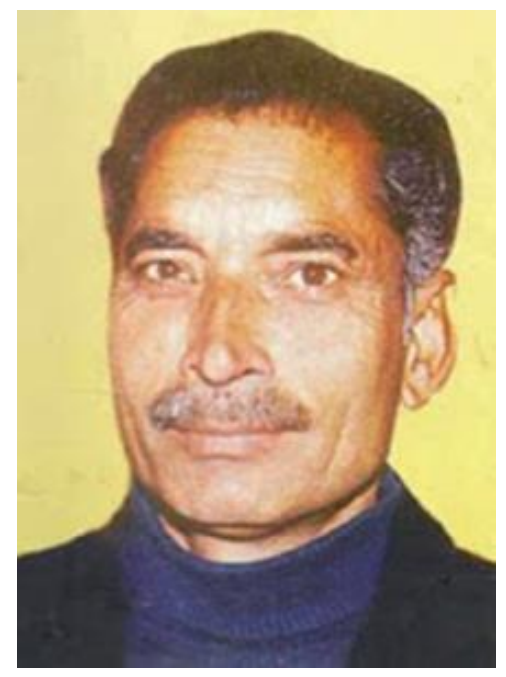

In Conversation with D.C. Chambial

\section{Rob Harle}

D.C. Chambial is a poet, short-story writer, critic, reviewer, translator. He writes in English, Hindi and Pahari language of Himachal Pradesh.

He has served HP Education Department at various places in Himachal Pradesh for about 38 years and retired as Associate Professor of English.

The Muse attracted him when he was still at high school and began to bear fruits in his college days. His first poem appeared in Skylark, an international magazine of poetry in 1979. His first collection of poems, Broken Images (1983) has since been followed by seven more anthologies: The Cargoes of the Bleeding Hearts \& Other Poems (1984), Perceptions (1986), Gyrating Hawks \& Sinking Roads (1996), Before the Petals Unfold (2002), This Promising Age \& Other Poems (2004), Mellow Tones (2009), and Words (2010). All these eight volumes have been published in one book - Words: 1979-2010 (2012) - by Aadi Publications from Jaipur. In 2014, he published Hour of Antipathy. Currently working on another anthology to be published later in 2017.

His poems have also been translated into several languages; his English poems have been published world-wide. He participated in Word Congress of Poets in Madras and 6th World Poetry Day in Gangtok (Sikkim) besides many UGC Seminars of Indian English Poetry and Literature.

Edits Poetcrit (since 1988), an international peer-reviewed journal devoted to literary criticism and contemporary poetry.

Winner of several medals (Gold, Silver, and Bronze) and awards from USA, Australia and India including the Michael Madhusudan Academy Award (1995) and Lifetime Achievement Award from Intercontinental Poetry Academy (2009).Contact: editorpoetcrit@gmail.com

In Conversation with D.C. Chambial. Rob Harle. Writers in Conversation Vol. 4 no. 1, February 2017. http://fhrc.flinders.edu.au/writers in conversation/ 
Q. Hello D.C. thanks for talking with us. This interview will be read around the world not just by your Indian colleagues, so could we start by you telling us a little about your childhood, schooling and tertiary education in a personal way?

A. Yes, let us start from the beginning. I was born, in September 1950, at Bajrol, a remote village of erstwhile Punjab. After reorganisation of states in 1966, our Kangra district was merged with Himachal Pradesh. I had my primary education in the local Primary School. At that time, this school imparted instructions only up to fourth standard. Thereafter, those of us, who wanted to attend middle school, had to travel on foot for about six kilometres from our place. I remained in that school for another four years and passed my eighth standard in 1964. Then I joined the nearest High School, which was about eight kilometres from my place and passed matriculation exam in 1966.

There were only about half a dozen colleges in Himachal Pradesh. The nearest college, at that time was Government College Dharamshala about 100 kilometres from my place. For college education, I had to go there. I joined college in 1966 and graduated in bio-sciences in 1970. Thereafter, I passed Bachelor of Education in 1971 from College of Education, also at Dharamshala. I started my career as a Science master, but right from my school days I had a strong desire to study literature. So, later on I pursued my studies for post-graduation in English literature. For PhD, I preferred Indian English poetry and studied the poetry of Krishna Srinivas, Shiv K. Kumar, and O. P. Bhatnagar for death and suffering.

So far as my childhood is concerned, we never had even the modern toys, during those days. Earthen toys and some selected stones used to be our toys. During our school holidays in July and August, we used to take our cattle and sheep for grazing. There we would weave some long ropes of the grass and tie it around a branch of the Banyan tree and enjoy swinging besides doing our home work.

Our village, being a remote village, had no road not to speak of any means of modern transportation. We had to travel all distances on foot. I cannot forget an incident of my life, when I had to run for two hours through the hills up and down, cross streams to and from my village. Once, my mother fell ill and the local vaidya (village doctor), prescribed some medicines that were available only at Sujanpur, about 15 kilometers away from our place. He told that it has to be brought as soon as possible. I ran to Sujanpur and returned with the medicines in about two hours. This is how I spent my childhood.

\section{Q. You have been involved in education for many years, recently retiring as Associate Professor of English. Do you miss the interaction with students and the pedagogical process, or do you now have more free time to devote to writing?}

A. Yes, it is true that $\mathrm{I}$, certainly, miss active interaction with my students. But, even in my retired life, I have been guiding students leading to their MPhil and PhD degrees. Not only this, whenever some students, really desiring for instructions/guidance in English language and literature come to me, I help them by sparing some time out of my schedule. I edit a journal, besides my creative and

In Conversation with D.C. Chambial. Rob Harle. Writers in Conversation Vol. 4 no. 1, February 2017. http://fhrc.flinders.edu.au/writers in conversation/ 
critical writings. Thus, I remain busy with my work and enjoy it. Even in my retired life, I never find myself without work. I think teaching and learning is a continuous process. It only ends with one's last breath. Others, who have nothing to do, find it hard to kill time, but I wish there were some more time!

Naturally, now, I have more time to devote to writing and editing. It wasn't so during my pre-superannuation days. Then I had to curtail my sleeping hours.

Q. Although you have written, edited and co-edited a number of books of criticism, including a critique of the poetry of Krishna Srinivas and O.P. Bhatnagar, it seems your main concern is writing poetry. Is this correct or do you also balance your time between writing poetry and short stories?

A. Yes, I concentrate on poetry writing only. I have written only about half a dozen stories and wish to write more stories. But, I think my temperament has conditioned me to write only poetry. I can't sit for long contemplating and writing stories. It is only lop-sided. More poetry and less stories.

Q. I should also mention that you are a tri-lingual author (English, Hindi \& Pahari) and have been involved extensively in the translation of poetry in these languages. Firstly, do you find translating as personally satisfying as writing your own poetry? Secondly, could you explain the difficulties in translating poetry, especially from a language like Hindi to English? I mean translating a technical manual is fairly straightforward but poetry with its subtle use of language and emotional impact is surely a different matter?

A. In this regard, I agree with you that in poetry translation of subtle language and emotions does create some level of difficulty. Though, it is not as satisfying as writing my poetry. It is very difficult to capture the actual mental state of the original writer when doing the translation. But, an effort towards that direction gives utmost joy. A translator for a while tries to live the life of the poet, whom he wants to translate. Sometimes the work in target language (TL) becomes nearer to its original work in the source language (SL). When it happens so, it gives immense joy to the person engaged in transferring it to the target language.

Yes, I agree with you that translation from Hindi to English, especially in poetry, poses two types of problems: one, syntactical, and the other, emotional transference. The syntax of two languages is never the same. While in English, it is subject-verb-object (SVO); in Hindi, it is subjectobject-verb (SOV). The emotional transference of ideas from source language (SL) to target language (TL) poses great difficulty. It arises from the vocabulary. The vocabulary of two languages is never equivalent. It suggests only nearness in meaning and emotion. To capture the emotions of the writer of the source language further makes it difficult for the work to be rendered in the target language (TL). It demands, of its practitioner, a steady effort and vast knowledge of the vocabulary of both the languages.

In Conversation with D.C. Chambial. Rob Harle. Writers in Conversation Vol. 4 no. 1, February 2017. http://fhrc.flinders.edu.au/writers in conversation/ 
Q. You have published to date eight volumes of poetry, the latest I believe is Words: $1979-2010$ A Collection of Poems (Aadi Publishers. 2012). This is a wonderful contribution to the world of poetry. Could you tell us a little about your poetry writing process? Inspiration? Subject matter? Revision and fine tuning process?

A. My poetry writing is not a continuous process. For months, I may not write even a single poem and when the mood is on, I write more than one poems, one after the other, at a time. It is somewhat spontaneous with me.

An idea, a word, or an incident keeps on haunting the mind for days together. When the idea matures in mind, it seeks its transference from mind to paper and the poem is born. The best examples of it are 'This Promising Age' and 'A Cry for Peace'. The latest one is 'GMG: The Man of Allah'. It is based on a newspaper story about a person who embraced death while saving the life of tourists in a flood in Srinagar, India.

I consider revision more important than even writing. While writing, one puts down wordpicture/s as one visualises them in his imagination without caring for other aspects of the poem. Once the theme of the poem is captured (the creative part), then the formal aspects of the poem can be looked after (the technical part). The more one revises, the more embellished a work of art becomes. When I started writing, I thought every word perfect as it was put on the paper in the heat of the imagination. Revision was avoided. But as my writing progressed and I grew in age and matured in experience, my whole perspective about the writing of a poem has undergone a sea change. Now, even when the poems are published, I still find the need to revise them and I do that. Thus, revision makes the work of art/poem more finished, direct and clear to both, the reader and the writer.

Q. I find two prominent themes in your poetry. One is a deep spiritual, mystical questioning, the other a more practical materialist concern for the injustices of the world. Like the poet Shujaat Hussain's poetry, your work questions the unreasonable ways of humans. This has the effect of raising the questions in a rhetorical manner in the reader's mind which makes the questions more powerful and engaging. Is this a correct assessment or I have I missed other equally important themes?

A. You have very aptly caught the nerve of my poetry. One notices men and women running after material gain without caring for the human ethics. It is a race of man for Mammon. In fact both compete with each other. It imparts a pragmatic approach to life and a writer/poet tries his best to hold the mirror unto the society and shows what is good or bad there: What needs be appreciated or deplored and rejected. In the present day society, there is much to be censured and discarded; and, little to be valued and retained.

When the writer/poet feels despaired in such kind of an ambience in his/her milieu, s/he turns to spirituality to find solace there. Thus, spirituality and mystical questioning comes not only as succour, but also as a mental space, where the artist/poet seeks answers to the fallibility of the modern man far from the humbug and hullaballoo of this life.

In Conversation with D.C. Chambial. Rob Harle. Writers in Conversation Vol. 4 no. 1, February 2017. http://fhrc.flinders.edu.au/writers in conversation/ 
Q. I find your poetic style quite unique as your poems have a kind of staccato type of cadence which moves the poem along nicely, do you agree with this? Here's an example from your poem 'We Are Living':

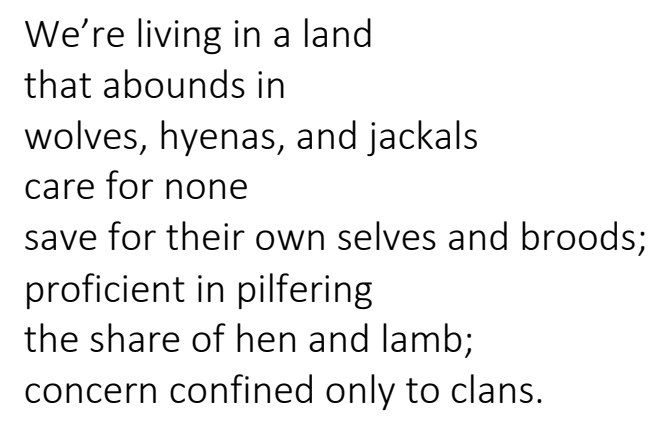

A. Yes, I completely agree with your observation. It expresses the anguish of the heart; hence, it becomes heavy and slow in movement in the lines quoted.

Q. If you had to pick one Indian writer and one Western writer who have had a major influence on your own writing, who would these be, and what was their main influence?

A. O. P. Bhatnagar and Robert Frost are the Indian and the American poets, who have influenced my writing. While Bhatnagar's poetry is apparent in my poems that exhibit socio-consciousness in them, Frost's poetry I love and he is my favourite poet besides John Keats. Frost's influence is manifest in my poems dealing with rural life.

Q. Rushdie once said, 'A poet's work ... to name the unnameable, to point at frauds, to take sides, start argument, shape the world and stop it from going to sleep.' Do you agree with Rushdie's statement and do you see your own work functioning in this way?

A. Yes. It is a writer's duty to point out what happens in the society and world in which he is living to hold a mirror unto them to see their true face. My poems that expose the inherent hypocrisy and corruption in the polity aim at the same point and direction, my objective in writing such poems is to awaken the thinking of the readers to that end. The reading public should not be silent spectators, but active participants in the argument. Once the readers, and public for that purpose, are awakened, keep a watch over the actions/frauds of their fellows in public life, how can world sleep. They have to be vigilant like the watchman! Thus, I fully subscribe to Rushdie's ideas.

Q. Poets can now publish their work on the Internet (websites, blogs, online journals and so on). Do you think this ease of publication, often without peer or editorial review, encourages a lowering in the quality of poetry?

A. True. Internet provides an immediate platform to express one's ideas in the shape of their works. They can also have a wider audience. However, I personally feel that a writer is in the hurry

In Conversation with D.C. Chambial. Rob Harle. Writers in Conversation Vol. 4 no. 1, February 2017. http://fhrc.flinders.edu.au/writers in conversation/ 
to publish and in that hurry some of the matter, which appears on Internet, is not finely finished. Such publications beyond doubt, in the absence of 'peer or editorial review', lower the quality of the work. Reviews and critical comments help to judge the work; these also point out the flaws, from which the writer can learn to improve him/herself in the works to follow. This type of instruction is not available for Internet (websites, blogs, online journals and so on) publications. I am of the view that before a writer decides to publish his/her work on Internet, s/he should thoroughly revise and re-revise umpteen times to bring it to a finely finished form as the protagonist, in William Carlos Williams' poem 'Fine Work with Pitch and Copper', does in the last two lines of the poem: 'picks up a copper strip / and runs his eye along it.'

Q. Thinking about this above Internet-communication phenomenon, do you think some good poets/writers who would not have been heard twenty years ago at least now can have an audience?

A. No doubt this phenomenon provides an opportunity to publish one's works without spending any money and instantly. Thus, those poets/writers who don't have money to expend in bringing out books by present day publishers, who demand money to publish works, can have this easy alternative to reach to their audience/readers. But they have to be very, very careful in this venture. Yes, it is the best way to reach the audience for such poets/writers who had no access to other means of written literature in the form of books and journals/magazines. Internet is making it possible for everyone to reach out to the vast audience.

Q. As an educator your answer to the following question is quite important: training may be beneficial to honing a poet's skills but it is my belief that without passion (or deep serious commitment) no amount of training will produce a really good poet, do you agree with this?

A. Here, too, I agree with you. Training can sharpen a poet's skill. A poem springs from heart only if one has dedication and zeal for poetry. One who does not have the natural talent for writing cannot become a good poet/writer merely by training. Writing instinct comes first; the skill follows it.

Q. At a personal satisfaction level do you prefer writing poetry or fiction stories?

A. As I have stated earlier, I prefer poetry writing to prose/fiction writing. It gives me satisfaction. I write poetry only.

Q. As I suggested earlier your poetry often has strong elements of humanitarianism and a deep spirituality. Would you care to expand on this and possibly the reasons for this outlook/philosophy?

A. One cannot alienate oneself from the human beings with whom one lives in one's vicinity or the world. Therefore, the concerns of fellow-beings are the concerns of the creative artist. He can

In Conversation with D.C. Chambial. Rob Harle. Writers in Conversation Vol. 4 no. 1, February 2017. http://fhrc.flinders.edu.au/writers in conversation/ 
never divorce these concerns. Hence, humanitarianism is bound to be the cardinal element of a writer/poet, and I am no exception to it.

Spirituality, naturally, creeps in when one finds such a wide gap between the rich and the poor. The poet/writer tries to find solutions to the prevalent unequal and unjust existence. To find solutions and respite from the present existential disharmony and dichotomy, the poet/writer crosses the walls of existential existence and lands in the calm environs of spirituality. Besides, spirituality is in our inherited psyche. I belong to a land that has given the world great spiritual seers and rishis; so, how I can remain alien to the spirituality that has come down to us/me from thousands of years?

Q. Indian literary scholars and academics such as yourself have a deep knowledge of all the great British writers such as Keats, Eliot, Shakespeare, Yeats, Dickens and Shelley. I don't hear much about the French masters such as Baudelaire or Rimbaud. How much do you attribute this to British colonialism in India?

A. We, in India, during colonial time were taught only British writers, which accounts for the knowledge of these writers. Even today same authors continue to be taught in our colleges and universities. Our initiation in literature starts with the British writers and in due course of time they become one with Indian literary scholars and academicians. It is only recently, after seventies, that we, in India, have started focusing on Indian writing. Even now some universities hesitate to include native writers in their curricula. So, you have explicitly found it to be the result of British colonialism in India and I fully concur with your observation.

Q. I think anthologies are a wonderful way to bring poets to the readers' attention, ones which they may not be familiar with. You are represented in numerous anthologies. Would you agree with this statement or do you think a collection of a poet's work is more efficacious in this regard?

A. Yes anthologies play vital role in bringing poets to readers' attention. Sometimes, even the poets included in an anthology are not familiar with one another. However, the compulsion of anthologies is that only 5-10 poems of a poet can be included in an anthology. No doubt, it widens the area of a poet's readership; from this restricted number of poems the readers can form only a partial view about the poet(s) included. To know completely about the ideology/ philosophy of a poet/writer, it becomes very important to read complete works. One cannot form an authentic opinion about the writer unless the reader has thorough knowledge of the writer's/poet's works. In this regard, I am, once again tempted to cite some lines from Pope's An Essay on Criticism:

A perfect judge will read each work of wit

With the same spirit that its author writ:

In Conversation with D.C. Chambial. Rob Harle. Writers in Conversation Vol. 4 no. 1, February 2017. http://fhrc.flinders.edu.au/writers in conversation/ 
And

'Tis not a lip, or eye, we beauty call,

But the joint force and full result of all.

I think, I have replied also to the last part of your question as plainly and honestly as I can.

Q. It is my personal belief that being authentic to oneself in an Existential sense is far more important than winning say a Pulitzer prize. 'Better to have no public, than to have no self.' Would you care to discuss this somewhat, anti-literary establishment view?

A. Writing comes from the endemic urge to create something new that gives satisfaction to an individual poet or writer. Authenticity and originality are of primordial significance rather than to write merely for prizes. Prizes or no prizes: it is immaterial for genuine writing. I, personally, subscribe to your view belief: 'Better to have no public, than to have no self.' When one starts writing only for prizes, one loses oneself. For me self is more important than all the prizes. When writing is sincere and true, it gets recognition not with the awards giving institutions but in the hearts and minds of the readers. I think this recognition to be everlasting.

Q. Charles Simic, one of my favourite poets said, 'Like our ancient ancestors who inhabited an animistic universe, the poet claims the interconnectedness and sentience of all things. This is what haunts: a world where magic is possible, where chance reigns, where metaphors have their supreme logic, where imagination is free and truthful.' Would you care to comment on this powerful insight of Simic's?

A. I must admit that I have not read much about Charles Simic. Nonetheless, the line that you have cited from him conveys much to the unity of world, both animal and the natural. A true poet knows no difference of lands, nations, people and their ways of life, their faiths. A poet envisions and is aware of the undifferentiated cosmic consciousness. When this statement is seen in the light of Vedic knowledge: Aham Brahmosmi (I am Brahman), it suggests that God is present everywhere and in everything, animate or inanimate, of this cosmos. Therefore, each and every object of this cosmos is part of Him. I find much similarity, rather complete synchronisation in the statement by Charles Simic and what the Vedas have propounded ages ago. This is what Charles Simic implies from 'animistic universe', and 'the interconnectedness and sentience of all things' is what a true poet tries to achieve through his words and works.

I believe that while going through my poems, you must have experienced this kind of 'sentience'. Somewhere Simic has stated: 'Words make love on the page like flies in the summer heat and the poet is merely the bemused spectator.' My poem, 'Words to Words' (212), may be an example in which the poet/protagonist remains 'the bemused spectator.'

All philosophical knowledge that we have today has come down to us from our ancient ancestors through our consciousness as well as in extant written form. It constitutes our nature and intuitive knowledge. I, personally, trust that in the creative universe of a poet, magic, chance,

In Conversation with D.C. Chambial. Rob Harle. Writers in Conversation Vol. 4 no. 1, February 2017. http://fhrc.flinders.edu.au/writers in conversation/ 
metaphor, and imagination have their undisputed place and position. Rudiments of life, existence and art have always remained unchanged through historical time and physical space, like the cardinal human sentiments. It all depends upon the artist as to how and to what extent s/he comes closer to them in his/her attempt to discern, capture and disseminate existential, universal and philosophical truth: the near and the far, the ephemeral and the philosophical.

Q: Poetry and to a slightly lesser extent short stories seem to be experiencing a resurgence in this era of high speed living, hedonism, consumerism and excessive input of images and mediadriven messages. Why do you think this might be the case?

A. Man is more busy now in this age of 'high speed living, hedonism, consumerism and excessive input of images and media-driven messages' and has less time to read longer works. Readers now wish to go through a work poem/story in one sitting and that also in the quickest manner in the shortest possible time. To me, this accounts for the resurrection of poetry and short story writing. I think you also concur with me.

Q. Contrary to this apparent resurgence it seems there are not many young poets (under 20 years) writing. As an educator do you find this the situation in India? If I am correct do you think it is because academic programs are now being tailored more and more to 'buck making' instantly after graduation, not as in the past where knowledge and cultural improvement was seen as a desirable end in itself?

A. Yes, it is for this very reason. Knowledge and culture are the victims here. Majority of the present day scholars are worried about their financial position and 'buck making' seems to be the only goal before them. The syllabi have also been programmed to meet that end. These syllabi do not care and cater to develop the inherent natural qualities of students. You are very true in your judgement that only a limited number of students start writing in their twenties.

Q. I have to ask the perennially asked question, what advice or guidance would you give to younger writers?

A. My advice to younger writers is to be sincere and committed to their writing. Honesty and dedication are the pillars of good writing. They should not try to ape or copy the style or themes of other writers. Style differs from individual to individual; no two writers can have similar style. One's sincerity leads to one's individual characteristic style and ultimate recognition.

Q. Is there anything I haven't touched on that you would like to add concerning your lifelong interest and participation in the literary world?

A. I think it has been a pleasant conversation and you have touched many new points that remained untouched in my earlier interviews/conversations. It is sufficient for the present.

In Conversation with D.C. Chambial. Rob Harle. Writers in Conversation Vol. 4 no. 1, February 2017. http://fhrc.flinders.edu.au/writers in conversation/ 
Q. One final question - your most recent book of poems, Words: $1979-2010$ A Collection of Poems is a kind of summing up of your poetry work with many wonderful, powerful poems. When can we look forward to your next personal volume of poetry?

A. The book cited by you is not my last. I have already published Hour of Antipathy in 2014 and script for one more book is almost ready, which I hope to publish by the first half of 2017.

Q. Thank you D.C. for sharing your story with us.

A. Thanks. It has been a pleasant discourse. It's my pleasure to talk to you.

Rob Harle is a writer, artist and academic reviewer. Writing work includes poetry, short fiction stories, academic essays and reviews of scholarly books, journals and papers. His work is published in journals, anthologies, online reviews, books and he has two volumes of his own poetry published: Scratches \& Deeper Wounds (1996) and Mechanisms of Desire (2012). Recent poetry has been published in: Rupkatha Journal (Kolkata); Nimbin Good Times (Nimbin); Beyond the Rainbow (Nimbin); Poetic Connections Anthology (2013); Indo-Australian Anthology of Contemporary Poetry (2013); Rhyme with Reason Anthology (2013); and Asian Signature (2013/16).

His art practice involves digital-computer art both for the web and print. His giclée images have been exhibited widely. He is especially interested in promoting the inclusion of visual art in academic, scientific and literary journals.

Formal studies include Comparative Religion, Philosophy, Literature and Psychotherapy. His thesis concerned Freud's notion of the subconscious and its relationship with Surrealist poetry.

Rob's main concern has been to explore and document the radical changes technology is bringing about. He coined the term technoMetamorphosis to describe this. This past concern is now moving towards helping to restore our abandoned metaphysical and spiritual modes of being through literature especially poetry.

He is currently on the editorial board of several literary and art/technology journals.

Artwork, Publications, Reviews and selected writings are available from his website www.robharle.com Email: harle@robharle.com

In Conversation with D.C. Chambial. Rob Harle. Writers in Conversation Vol. 4 no. 1, February 2017. http://fhrc.flinders.edu.au/writers in conversation/ 